\title{
Comparison of Irrigation Methods in Terms of Vegetative Growth of Potato (Solanum tuberosum L.) Cultivars
}

\author{
Shiwani*, A.K. Bhatia, Makhan Majoka and Pooja Rani
}

CCS Haryana Agricultural University, Hisar-125004 (Haryana), India

*Corresponding author

\begin{abstract}
A B S T R A C T
Keywords

Potato, Cultivars, Plant height, Drip irrigation, Furrow irrigation

Article Info

Accepted:

20 November 2018

Available Online:

10 December 2018

The studies were conducted at Research Farm of the Department of Vegetable Science during 2016-17 and 2017-18 to evaluate the effect of irrigation methods viz., drip and furrow irrigation on growth parameters of four potato cultivars viz., Kufri Pukhraj, Kufri Surya, Kufri Pushkar and Kufri Bahar. The experiment was laid out in randomized block design with four replications. The observations were recorded on plant emergence at 30 days, number of shoots per hill at 90 days and plant height at 30,60 and 90 days after planting. Results revealed that the drip irrigation gave highest value for all the growth parameters as compared to furrow irrigation. The Kufri Pushkar had maximum growth, whereas, the minimum plant emergence and plant height was recorded with Kufri Surya but the number of shoots per hill was recorded minimum in Kufri Pukhraj. Based on the two years results, the potato cultivar Kufri Pushkar with drip irrigation proved best for the growth for potato plants.
\end{abstract}

\section{Introduction}

Potato (Solanum tuberosum L.), also known as Irish potato and the king of vegetables, belonging to the family Solanaceae is one of the most important vegetable crops in the world and in terms of human consumption, it ranks 4th after wheat, rice and corn (Hassan, 2003). The Andean tuber crop was originally domesticated in South America and its worldwide dissemination was started after Columbus's voyages brought it to Europe in $16^{\text {th }}$ century. Potato is one of the main cash crops among vegetables, which is grown and consumed all round the world (Nyunza and Mwakaje, 2012). The countries like China, USA, Europe, Russian Federation, India and
Japan have the highest potato yield in the world. In world, India ranks $3 \mathrm{rd}$ in area, i.e., 18.28 million hectare and 2nd in the production, i.e., 364.87 million ton of potato (FAOSTAT, 2012). India is the second largest producer of potato in the world after China with the total area and production of 2.14 million hectares and of 48.60 million ton, respectively during 2016-17 (Anonymous, 2017). Potato is also one of the most important crops of Haryana, having area of 34.53 thousand ton with the production and productivity of 896.95 thousand MT and 25.98 t/ha, respectively (NHB, 2017). India stands at fourth place with respect to the production of potato in the world, but the productivity is very low as compared to other advanced 
countries. The higher productivity could be achieved by selection of proper varieties specific to areas and other agronomical practices. India being a vast country with varied agro-climatic regions, a single variety or hybrid may not be suitable for all the agroclimatic conditions. Hence, varieties are needed to be evaluating for specific regions (Amarananjundeswara, 2018).

Water is the key input in potato production and the problem of water management varies from region to region. Potato plants are sensitive to changes in soil moisture due to their shallow root system and improper irrigation management practices not only waste the expensive and scare water resources but also reduce the tuber yield and quality (Khalel, 2015). Therefore, quantity, frequency and method of irrigation always decide growth, yield, quality and storability of potato tubers (Shahnazari et al., 2007). The amount of water needed by the potato crop varies with soil type, temperature, humidity, air movement, plant and stem populations, varieties and cultural practices (Wiersema, 1987) but critical stages for irrigation are tuber initiation and tuber bulking (Abdallah, 1996). Further, the water resources are becoming scarce day by day and it has been predicted to get worsen globally due to extreme weather conditions like draught, flood, etc. The decline in water resources requires the development of new water saving strategies. Furrow and sprinkler methods of irrigation are widely used in potato because it is easy to do and requires low maintenance (Onder et al., 2005). There is a need for economizing water uses by replacing conventional method of irrigation to more efficient irrigation system i.e., drip irrigation, which saved approx. $45 \%$ water as compared to furrow irrigation system (Chongtham et al., 2016). The drip irrigation system offers opportunity for the precise application of water-soluble fertilizers and other nutrients to soil at appropriate times in desired concentrations than furrow irrigation. It can also reward farmers by giving them high crop yield if combined with good farming practices such as high yielding varieties, good soil management, proper fertilization, mechanization operations and improved seeds (Pair et al., 1975). Moreover, it reduces manmade environmental effects that involve water wastage, land reclamation with sewage, water waste from the cities and factories, converting them into agricultural crop productivity. Drip irrigation system was not widely used in potato production because of high cost of installation but now the cost has relatively decreased due to improved technology. Therefore, the study was undertaken to find the effect of irrigation methods on growth of potato cultivars.

\section{Materials and Methods}

The experiment was carried out at Research Farm of the Department of Vegetable Science, CCS Haryana Agricultural University, Hisar, Haryana during 2016-17 and 2017-18. Hisar is situated at latitude of $29^{\circ} 10^{\prime} \mathrm{N}$, longitude of $75^{\circ} 46^{\prime} \mathrm{E}$ and at the height of 215.2 meters above mean sea level and falls in semi-arid and sub-tropical region with hot and dry summer and severe cold in winter. The maximum temperature was ranged between 17.2 to $30.8^{\circ} \mathrm{C}$ and 17.3 to $30.8^{\circ} \mathrm{C}$, while the minimum was ranged between 6.0 to $12.8{ }^{\circ} \mathrm{C}$ and 2.5 to $14.8^{\circ} \mathrm{C}$ during both the years, respectively. The soil of experimental field was sandy loam. The treatments consisted of two irrigation methods, i.e., drip and furrow irrigation and four potato cultivars, i.e., Kufri Pukhraj, Kufri Surya, Kufri Pushkar and Kufri Bahar. The treatments were laid out in randomized block design with four replications. The planting was done manually by placing each tuber at $20 \mathrm{~cm}$ spacing in row and spacing between rows was at $60 \mathrm{~cm}$. The potato plants were irrigated at $40 \mathrm{~mm}$ depth in furrow irrigation, while the drip irrigation was 
applied at $10 \mathrm{~mm}$ depth during both the years. The fertilizers were applied as per the recommendations for potato crop in Haryana conditions (NPK @ 150:50:100 kg/ha). The recommended plant protection measures were also adopted when required for raising healthy potato crop. The haulm killing was done chemically with Gramoxone @ 7 ml/lt at 90 days of planting after taking necessary data. The data were recorded on percent plant emergence at 30 days, plant height at monthly interval and number of shoots per hill at the time of harvest.

\section{Statistical analysis}

The statistical software OPSTAT (http:// 14.139.232.166/opstat/index.asp), developed by CCS, Haryana Agricultural University, Hisar (Haryana), India was used for statistical analysis of data (Sheoran, 2010).

\section{Results and Discussion}

The drip irrigation and potato cultivars had significant effect on all the growth parameters during both the years. The mean plant emergence ( 86.20 and $90.52 \%$ ) was recorded maximum with drip irrigation, while the minimum mean plant emergence (83.19 and $84.47 \%$ ) was observed with treatment where furrow irrigation was applied during 2016-17 and 2017-18, respectively (Table 1). The results obtained during both the years were in good accordance with those of Chawla and Narda (2000) and Shiwani et al., (2017) who stated that the adequate amount and frequency of irrigation stimulates crop growth and development of most of the vegetable crops. Further, the uneven distribution and insufficient use of irrigation water leads to deep percolation and leaching losses of nutrients that might be the reason for lower percent emergence (Sankar et al., 2008). Different potato cultivars showed variable percent emergence. The maximum mean plant emergence (88.67 and 92.88\%) was found with potato cultivar Kufri Pushkar, whereas, the minimum mean plant emergence (80.41 and $82.65 \%$ ) was recorded with Kufri Surya during 2016-17 and 2017-18, respectively. These results confirm the findings of Yadav et al., (2017) and Chongtham et al., (2016). The interaction effect was found non-significant which ranged between 79.96 to $90.77 \%$ and 80.51 to $95.83 \%$ during $2016-17$ and $2017-18$, respectively (Table 1).

The results of various levels of irrigation methods and potato cultivars with their interaction in relation to plant height at monthly intervals are shown below (Table 2, Table 3 and Table 4). The irrigation methods, potato cultivars and their interaction differed significantly with regard to plant height at monthly intervals. In 2016-17, the maximum plant height at 30, 60 and 90 days (40.04, 50.10 and $60.25 \mathrm{~cm}$ ) was found under drip irrigation, whereas, the minimum (36.07, 47.30 and $56.21 \mathrm{~cm}$ ) was recorded under furrow irrigation. During 2017-18, the highest value for plant height at 30,60 and 90 days $(42.37,52.02$ and $64.11 \mathrm{~cm})$ was found under drip irrigation, while the lowest value (37.06, 48.88 and $58.88 \mathrm{~cm}$ ) was noted under furrow irrigation.

The results of present investigation were in line with the findings of Chawla and Narda (2001), Ferreira and Carr (2002), Yuan et al., (2003) and Badr et al., (2012). According to Kashyap and Panda (2003), the growth of potato plant responds positively to frequent irrigation. The higher frequency and better uniformity of irrigation water in drip system could be attributed to maximum plant height under drip irrigation as compared to furrow irrigation (Chongtham et al., 2016). The reduction in plant height in potato varieties under furrow irrigation might be due to stomata closure and reduced $\mathrm{Co}_{2}$ in soil moisture stress, which hindered the 
photosynthesis and other biochemical processes and ultimately nutrient uptake of plants hampered (Fitsum et al., 2016).

The potato cultivars also had significant effect on plant height at monthly interval as shown in Table 2, 3 and 4. During 2016-17, the maximum plant height at 30,60 and 90 days $(41.10,53.26$ and $62.37 \mathrm{~cm})$ of planting was recorded in Kufri Pushkar followed by Kufri Bahar $(39.01,50.32$ and $59.29 \mathrm{~cm}$ ), whereas, the minimum plant height at 30,60 and 90 days $(34.87,44.01$ and $54.08 \mathrm{~cm}$ ) after planting was found in Kufri Surya.

Table.1 Effect of irrigation methods on plant emergence (\%) at 30 days of potato cultivars

\begin{tabular}{|c|c|c|c|c|c|c|c|c|c|c|}
\hline \multirow{2}{*}{$\begin{array}{l}\text { Irrigation } \\
\text { methods }\end{array}$} & \multicolumn{5}{|c|}{ 2016-17 } & \multicolumn{5}{|c|}{ 2017-18 } \\
\hline & $\begin{array}{c}\text { Kufri } \\
\text { Pukhraj }\end{array}$ & $\begin{array}{l}\text { Kufri } \\
\text { Surya }\end{array}$ & $\begin{array}{c}\text { Kufri } \\
\text { Pushkar }\end{array}$ & $\begin{array}{l}\text { Kufri } \\
\text { Bahar }\end{array}$ & Mean & $\begin{array}{c}\text { Kufri } \\
\text { Pukhraj }\end{array}$ & $\begin{array}{l}\text { Kufri } \\
\text { Surya }\end{array}$ & $\begin{array}{c}\text { Kufri } \\
\text { Pushkar }\end{array}$ & $\begin{array}{l}\text { Kufri } \\
\text { Bahar }\end{array}$ & Mean \\
\hline $\mathbf{I}_{1}:$ Drip & 84.79 & 80.85 & 90.77 & 88.38 & 86.20 & 89.32 & 84.80 & 95.83 & 92.11 & 90.52 \\
\hline$I_{2}$ : Furrow & 82.76 & 79.96 & 86.58 & 83.46 & 83.19 & 82.26 & 80.51 & 89.93 & 85.19 & 84.47 \\
\hline Mean & 83.78 & 80.41 & 88.67 & 85.92 & & 85.79 & 82.65 & 92.88 & 88.65 & \\
\hline Factors & Irrigation & Variety & \multicolumn{3}{|c|}{ Irrigation $x$ Variety } & Irrigation & Variety & \multicolumn{3}{|c|}{ Irrigation x Variety } \\
\hline $\mathrm{SE}(\mathrm{m}) \pm$ & 0.49 & 0.69 & \multicolumn{3}{|c|}{0.97} & 0.34 & 0.48 & \multicolumn{3}{|c|}{0.68} \\
\hline C.D. & 1.44 & 2.04 & \multicolumn{3}{|c|}{ N.S. } & 1.01 & 1.42 & \multicolumn{3}{|c|}{ N.S. } \\
\hline
\end{tabular}

Table.2 Effect of irrigation methods on plant height $(\mathrm{cm})$ at 30 days of potato cultivars

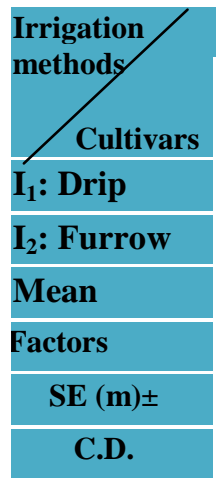

\begin{tabular}{|c|c|c|c|c|}
\hline \multicolumn{5}{|c|}{ 2016-17 } \\
\hline $\begin{array}{c}\text { Kufri } \\
\text { Pukhraj }\end{array}$ & $\begin{array}{c}\text { Kufri } \\
\text { Surya }\end{array}$ & $\begin{array}{c}\text { Kufri } \\
\text { Pushkar }\end{array}$ & $\begin{array}{c}\text { Kufri } \\
\text { Bahar }\end{array}$ & Mean \\
\hline 38.86 & 37.65 & 42.90 & 40.74 & $\mathbf{4 0 . 0 4}$ \\
\hline 35.65 & 32.09 & 39.29 & 37.28 & $\mathbf{3 6 . 0 7}$ \\
\hline $\mathbf{3 7 . 2 5}$ & $\mathbf{3 4 . 8 7}$ & $\mathbf{4 1 . 1 0}$ & $\mathbf{3 9 . 0 1}$ & \\
\hline Irrigation & Variety & Irrigation x Variety \\
\hline 0.17 & 0.24 & \multicolumn{3}{|c|}{0.34} \\
\hline 0.50 & 0.70 & & 0.99 \\
\hline
\end{tabular}

\begin{tabular}{|c|c|c|c|c|}
\hline \multicolumn{5}{|c|}{$\mathbf{2 0 1 7 - 1 8}$} \\
$\begin{array}{c}\text { Kufri } \\
\text { Pukhraj }\end{array}$ & $\begin{array}{c}\text { Kufri } \\
\text { Surya }\end{array}$ & $\begin{array}{c}\text { Kufri } \\
\text { Pushkar }\end{array}$ & $\begin{array}{c}\text { Kufri } \\
\text { Bahar }\end{array}$ & Mean \\
\hline 41.85 & 40.55 & 44.72 & 42.36 & $\mathbf{4 2 . 3 7}$ \\
\hline 36.36 & 34.94 & 39.01 & 37.91 & $\mathbf{3 7 . 0 6}$ \\
\hline $\mathbf{3 9 . 1 0}$ & $\mathbf{3 7 . 7 5}$ & $\mathbf{4 1 . 8 7}$ & $\mathbf{4 0 . 1 3}$ & \\
\hline Irrigation & Variety & \multicolumn{3}{|c|}{ Irrigation x Variety } \\
\hline 0.08 & 0.11 & \multicolumn{3}{|c|}{0.16} \\
\hline 0.24 & 0.33 & & 0.47 \\
\hline
\end{tabular}

Table.3 Effect of irrigation methods on plant height $(\mathrm{cm})$ at 60 days of potato cultivars

\begin{tabular}{l}
$\begin{array}{l}\text { Irrigation } \\
\text { methods }\end{array}$ \\
\multicolumn{1}{c}{ Cultivars } \\
\hline $\mathbf{I}_{1}$ : Drip \\
\hline $\mathbf{I}_{2}$ : Furrow \\
\hline Mean \\
\hline Factors \\
\hline SE $(m) \pm$ \\
\hline C.D. \\
\hline
\end{tabular}

\begin{tabular}{|c|c|c|c|c|}
\hline \multicolumn{5}{|c|}{$\mathbf{2 0 1 6 - 1 7}$} \\
\hline $\begin{array}{c}\text { Kufri } \\
\text { Pukhraj }\end{array}$ & $\begin{array}{c}\text { Kufri } \\
\text { Surya }\end{array}$ & $\begin{array}{c}\text { Kufri } \\
\text { Pushkar }\end{array}$ & $\begin{array}{l}\text { Kufri } \\
\text { Bahar }\end{array}$ & Mean \\
\hline 49.34 & 45.95 & 53.77 & 51.35 & $\mathbf{5 0 . 1 0}$ \\
\hline 45.10 & 42.06 & 52.76 & 49.30 & $\mathbf{4 7 . 3 0}$ \\
\hline $\mathbf{4 7 . 2 2}$ & $\mathbf{4 4 . 0 1}$ & $\mathbf{5 3 . 2 6}$ & $\mathbf{5 0 . 3 2}$ & \\
\hline Irrigation & Variety & Irrigation x Variety \\
\hline 0.16 & 0.22 & \multicolumn{3}{|c|}{0.31} \\
\hline 0.46 & 0.65 & & 0.92 \\
\hline
\end{tabular}

\begin{tabular}{|c|c|c|c|c|}
\hline \multicolumn{5}{|c|}{$2017-18$} \\
\hline $\begin{array}{c}\text { Kufri } \\
\text { Pukhraj }\end{array}$ & $\begin{array}{c}\text { Kufri } \\
\text { Surya }\end{array}$ & $\begin{array}{c}\text { Kufri } \\
\text { Pushkar }\end{array}$ & $\begin{array}{l}\text { Kufri } \\
\text { Bahar }\end{array}$ & Mean \\
\hline 51.56 & 48.43 & 54.65 & 53.45 & $\mathbf{5 2 . 0 2}$ \\
\hline 47.84 & 46.33 & 51.64 & 49.73 & $\mathbf{4 8 . 8 8}$ \\
\hline $\mathbf{4 9 . 7}$ & $\mathbf{4 7 . 3 8}$ & $\mathbf{5 3 . 1 4}$ & $\mathbf{5 1 . 5 9}$ & \\
\hline Irrigation & Variety & Irrigation x Variety \\
\hline 0.10 & 0.14 & \multicolumn{3}{|c|}{0.19} \\
\hline 0.29 & 0.41 & \multicolumn{3}{|c|}{0.57} \\
\hline
\end{tabular}


Table.4 Effect of irrigation methods on plant height $(\mathrm{cm})$ at 90 days of potato cultivars

\begin{tabular}{|c|c|c|c|c|c|c|c|c|c|c|}
\hline \multirow{2}{*}{$\begin{array}{l}\text { Irrigation } \\
\text { methods }\end{array}$} & \multicolumn{5}{|c|}{ 2016-17 } & \multicolumn{5}{|c|}{ 2017-18 } \\
\hline & $\begin{array}{c}\text { Kufri } \\
\text { Pukhraj }\end{array}$ & $\begin{array}{l}\text { Kufri } \\
\text { Surya }\end{array}$ & $\begin{array}{c}\text { Kufri } \\
\text { Pushkar }\end{array}$ & $\begin{array}{l}\text { Kufri } \\
\text { Bahar }\end{array}$ & Mean & $\begin{array}{c}\text { Kufri } \\
\text { Pukhraj }\end{array}$ & $\begin{array}{l}\text { Kufri } \\
\text { Surya }\end{array}$ & $\begin{array}{c}\text { Kufri } \\
\text { Pushkar }\end{array}$ & $\begin{array}{l}\text { Kufri } \\
\text { Bahar }\end{array}$ & Mean \\
\hline $\mathbf{I}_{1}:$ Drip & 59.04 & 56.84 & 64.67 & 60.45 & 60.25 & 61.91 & 59.03 & 68.59 & 66.90 & 64.11 \\
\hline$I_{2}:$ Furrow & 55.31 & 51.31 & 60.08 & 58.13 & 56.21 & 59.10 & 53.74 & 62.65 & 60.01 & $\mathbf{5 8 . 8 8}$ \\
\hline Mean & 57.18 & 54.08 & 62.37 & 59.29 & & 60.51 & 56.39 & 65.62 & 63.45 & \\
\hline Factors & Irrigation & Variety & \multicolumn{3}{|c|}{ Irrigation x Variety } & Irrigation & Variety & \multicolumn{3}{|c|}{ Irrigation x Variety } \\
\hline $\mathrm{SE}(\mathrm{m}) \pm$ & 0.26 & 0.37 & \multicolumn{3}{|c|}{0.53} & 0.30 & 0.43 & \multicolumn{3}{|c|}{0.60} \\
\hline C.D. & 0.78 & 1.10 & \multicolumn{3}{|c|}{1.56} & 0.90 & 1.27 & \multicolumn{3}{|c|}{1.79} \\
\hline
\end{tabular}

Table.5 Effect of irrigation methods on number of shoots per hill at 90 days of potato cultivars

\begin{tabular}{|c|c|c|c|c|c|c|c|c|c|c|}
\hline \multirow{2}{*}{$\begin{array}{l}\text { Irrigation } \\
\text { methods }\end{array}$} & \multicolumn{5}{|c|}{ 2016-17 } & \multicolumn{5}{|c|}{ 2017-18 } \\
\hline & $\begin{array}{c}\text { Kufri } \\
\text { Pukhraj }\end{array}$ & $\begin{array}{l}\text { Kufri } \\
\text { Surya }\end{array}$ & $\begin{array}{c}\text { Kufri } \\
\text { Pushkar }\end{array}$ & $\begin{array}{l}\text { Kufri } \\
\text { Bahar }\end{array}$ & Mean & $\begin{array}{c}\text { Kufri } \\
\text { Pukhraj }\end{array}$ & $\begin{array}{l}\text { Kufri } \\
\text { Surya }\end{array}$ & $\begin{array}{c}\text { Kufri } \\
\text { Pushkar }\end{array}$ & $\begin{array}{l}\text { Kufri } \\
\text { Bahar }\end{array}$ & Mean \\
\hline $\mathbf{I}_{1}:$ Drip & 5.63 & 6.39 & 6.70 & 6.55 & 6.32 & 5.97 & 6.48 & 6.84 & 6.77 & 6.51 \\
\hline $\mathrm{I}_{2}:$ Furrow & 5.32 & 5.46 & 6.39 & 5.58 & 5.68 & 5.52 & 5.81 & 6.60 & 5.92 & 5.96 \\
\hline Mean & 5.48 & 5.92 & 6.54 & 6.07 & & 5.75 & 6.15 & 6.72 & 6.35 & \\
\hline Factors & Irrigation & Variety & \multicolumn{3}{|c|}{ Irrigation $\mathrm{x}$ Variety } & Irrigation & Variety & \multicolumn{3}{|c|}{ Irrigation $\mathrm{x}$ Variety } \\
\hline $\mathrm{SE}(\mathrm{m}) \pm$ & 0.04 & 0.05 & \multicolumn{3}{|c|}{0.07} & 0.05 & 0.07 & \multicolumn{3}{|c|}{0.09} \\
\hline C.D. & 0.11 & 0.16 & \multicolumn{3}{|c|}{0.22} & 0.14 & 0.19 & \multicolumn{3}{|c|}{0.27} \\
\hline
\end{tabular}

During 2017-18, the maximum plant height at 30, 60 and 90 days (41.87, 53.14 and 65.62 $\mathrm{cm})$ of planting was registered with Kufri Pushkar followed by Kufri Bahar (40.13, 51.59 and 63.45), while the minimum plant height $(37.75,47.38$ and $56.39 \mathrm{~cm})$ was found with Kufri Surya. The results are in close confirmatory with the findings of Chongtham et al., (2016), Yadav et al., (2017) and Luthra et al., (2017). The different behaviour of potato varieties with reference to growth parameters might be due to their genetic factors (Patel et al., 2006).

The interaction effect of both the treatments was observed significant regarding plant height at 30, 60 and 90 days after planting. During 2016-17, the maximum plant height at 30, 60 and 90 days (42.90, 53.77 and 64.67 $\mathrm{cm})$ was noted with Kufri Pushkar under drip irrigation, whereas, the minimum (32.09,
42.06 and $51.31 \mathrm{~cm}$ ) was found in Kufri Surya under furrow irrigation. During 201718, the potato cultivar Kufri Pushkar with drip irrigation $(44.72,54.65$ and $68.59 \mathrm{~cm}$ ) gave maximum plant height, while the minimum (34.94, 46.33 and $53.74 \mathrm{~cm})$ was recorded with Kufri Surya under furrow irrigation.

The data regarding number of shoots per hill at 90 days have been presented in Table 5 . The data indicate that the both irrigation methods and cultivars had significant effect on number of shoots per hill at 90 days after planting during both the years. The highest number of shoots per hill (6.32 and 6.51) was recorded with treatment where drip irrigation was applied, while the lowest value for number of shoots per hill (5.68 and 5.96) was observed with furrow irrigation system during 2016-17 and 2017-18, respectively. These findings are in good accordance with the 
results of Chawla and Narda (2000), Ferreira and Carr (2002), Yuan et al., (2003) and Badr et al., (2012). The increment in growth parameters under drip irrigation could be due to direct availability of water at root zone that increased photosynthetic ability of the plants and very important for transpiration and tissue formation that might increase number of shoots per hill also (Ahmed et al., 2007).

Among the potato cultivars, Kufri Pushkar showed significantly higher number of shoots per hill (6.54 and 6.72), whereas, the minimum value for number of shoots per hill (5.48 and 5.75) was observed with potato cultivar Kufri Pukhraj during 2016-17 and 2017-18, respectively. These results confirm the findings of Yadav et al., (2017), Chongtham et al., (2016), Luthra et al., (2017) and Amarananjundeswara et al., (2018). During both the years, the interaction effect of different irrigation methods and potato cultivars was found significant regarding number of shoots per hill at 30, 60 and 90 days after planting (Table 5). The uppermost value for number of shoots per hill (6.70 and 6.84) at 30, 60 and 90 days was registered with cultivar Kufri Pushkar under drip irrigation followed by Kufri Bahar (6.55 and 6.77) under same irrigation method, while Kufri Pukhraj showed minimum value (5.32 and 5.52) for number of shoots per hill at 30, 60 and 90 days with furrow irrigation during 2016-17 and 2017-18, respectively.

In conclusion, the drip irrigation gave better growth of potato plants when compared with furrow irrigation. In addition, Kufri Pushkar followed by Kufri Bahar had highest value for all the growth parameters during 2016-17 and 2017-18. Based on investigation of two years, it may be concluded that the drip irrigation with Kufri Pushkar proved best for the growth of potato plants that could ultimately leads to higher yield.

\section{References}

Abdallah, S.A.M. 1996. Studies on the application of antitranspirant and water regimes on potatoes grown in calcareous soils. M.Sc. thesis, Faculty of Agriculture, Alexandria University, Egypt.

Ahmed, H.G., Magaji, M.D., Yakutu, A.I., Aliyu, L. and Singh, A. 2007. Response to irrigation interval and clove size in semiarid, Nigeria. Journal of Plant Sciences. 2: 202-208.

Amarananjundeswara, H., Prasad, P. S., Shetty, S. and Sandhya, G. C. 2018. Evaluation of promising potato varieties for yield potentiality and late blight disease tolerance in southern dry zone of Karnataka, India. International Journal of Current Microbiology and Applied Science. 7(2): 341-350.

Anonymous. 2017. Area and Production of Vegetable Crops. Directorate of Horticulture, Panchkula, Government of Haryana.

Badr, M. A., El-Tohamy, W. A. and Zaghloul, A. M. 2012. Yield and water use efficiency of potato grown under different irrigation and nitrogen levels in an arid region. Agricultural Water Management, 110: 915.

Chawla, J. K. and Narda, N. K. 2000. Growth parameters of trickle fertigated potato (Solanum tuberosum L.). Indian Journal of Agricultural Sciences. 70(11): 747-752.

Chawla, J. K. and Narda, N. K. 2001. Economy in water and fertilizer use in trickle fertigated potato 1. Irrigation and Drainage. The journal of the International Commission on Irrigation and Drainage, 50(2): 129-137.

Chongtham, S.K., Patel, C.K., Patel, R.N., Patel, J.K., Patel, J.M., Zapadiya, D.M., Patel, D.H. and Patel, C.R. 2016. Growth, yield, economics, water and nutrient use efficiency of potato as influenced by different methods of drip fertigation and varieties. International Journal of Agriculture Sciences. 8(38): 1787-1790.

FAOSTAT. 2012. Statistical databases. Food and Agriculture Organization of the United Nations.

Ferreira, T.C. and Carr, M.K.V. 2002. Responses 
of potatoes (Solanum tuberosum L.) to irrigation and nitrogen in a hot, dry climate: I. Water use. Field Crops Research. 78(1): 51-64.

Fitsum, G., Woldetsadik, K. and Alemayhu, Y. 2016. Effect of irrigation depth and nitrogen levels on growth and bulb yield of onion (Allium cepa L.) at Algae, Central Rift Valley of Ethiopia. International Journal of Life Sciences. 5(3): 152-162.

Hassan, A.A. 2003. Potato. Dar-AL-Arabiya Publication, Cairo, Egypt. p. 213.

Kashyap, P.S. and Panda, R.K. 2003. Effect of irrigation scheduling on potato crop parameters under water stressed conditions. Agricultural Water Management. 59(1): 4966.

Khalel, A.M.S. 2015. Effect of drip irrigation intervals and some antitranspirants on the water status, growth and yield of potato (Solanum tuberosum L.). Journal of Agricultural Science and Technology. 5: 15-23.

NHB. 2017. Indian Horticulture Database. National Horticulture Board, Ministry of Agriculture and Farmers Welfare Government of India.

Nyunza, G. and Mwakije, A.E.G. 2012. Analysis of round potato marketing in Tanzania: The case of Rungwe district, Tanzania. International journal of Business and Social Sciences. 3(23): 86-96.

Onder, S., Caliskan, M. E., Onder, D. and Caliskan, S. 2005. Different irrigation methods and water stress effects on potato yield and yield components. Agricultural Water Management. 73(1): 73-86.

Pair, C. H., Kimberly, I., Hinz, W. W., Reid, C. and Frost, K. R. 1975. Sprinkler Irrigation, Fourth Edition. Connecticut Avenue.

Patel, R.N., Patel, N.H., Pandey, S.K., Kanbi,
V.H. and Patel, C.K. 2006. Yield performance and shelf life of some advanced potato hybrids in Gujarat. Potato Journal. 33(3-4): 149-150.

Sankar, V., Lawande, K.E. and Tripathi, P.C. 2008. Effect of micro irrigation practices on growth and yield of garlic. Journal of Spices and Aromatic Crops. 17(3): 230234.

Shahnazari, A., Liu, F., Andersen, M.N., Jacobsen, S.E. and Jensen, C.R. 2007. Effects of partial root-zone drying on yield, tuber size and water use efficiency in potato under field conditions. Field Crops Research. 100: 117-124.

Sheoran, O.P. 2010. Online statistical analysis (OPSTAT) software developed by Chaudhary Charan Singh Haryana Agricultural University, Hisar, India. http://www.hau.ernet.in/opstat.html.

Shiwani, Lal, M., Rani, P. and Rana, M. K., 2017. Effect of withholding irrigation on yield contributing traits of garlic (Allium sativum L.). Agricultural Research Journal. 54(4): 480-483.

Wiersema, S.G. 1987. Effect of stem density on potato production. Technical Information Bulletin, International Potato Center, Lima, Peru. p. 16.

Yadav, S. K., Singh, G.K., Jain, V.K. and Tiwari, A. 2017. Response of potato (Solanum tuberosum L.) cultivars to different levels of nitrogen. International Journal of Current Microbiology and Applied Sciences. 6(8): 2734-2739.

Yuan, B.Z., Nishiyama, S. and Kang, Y. 2003. Effects of different irrigation regimes on the growth and yield of drip-irrigated potato. Agricultural Water Management. 63(3): 153-167.

\section{How to cite this article:}

Shiwani, A.K. Bhatia, Makhan Majoka and Pooja Rani. 2018. Comparison of Irrigation Methods in Terms of Vegetative Growth of Potato (Solanum tuberosum L.) Cultivars. Int.J.Curr.Microbiol.App.Sci. 7(12): 2984-2990. doi: https://doi.org/10.20546/ijcmas.2018.712.342 